\title{
The Demographic Stretch of the Arc of Life: Social and Cultural Changes That Follow the Demographic Transition
}

\author{
Ariel Pablos-Mendez, ${ }^{a}$ Scott R Radloff, ${ }^{b}$ Kamiar Khajavi, ${ }^{a}$ Sally Ann Dunst ${ }^{b}$
}

\begin{abstract}
The demographic transition from high to low levels of mortality and fertility brings about changes that stretch the "arc of life," making each stage of life longer and creating new ones-a phenomenon we call "the demographic stretch." This stretch can transform societal structure, for example, by extending childhood, shifting working ages up, delaying marriage and childbearing, improving women's status and equity, and pushing the burden of chronic disease and disability to older ages. Global health efforts must address the resultant economic and social changes.
\end{abstract}

$\mathbf{T}$ he demographic transition, when countries shift from high to low levels of mortality and fertility, has been underway for 2 centuries, with differences in onset and pace across countries and regions of the world. ${ }^{1-3}$ Over the course of the transition, average life expectancy more than doubles, from about 40 years to 80 years, while the average fertility rate declines from about 7 children per woman to 2.5 children per woman-nearing replacement levels.

Living longer does not mean simply adding more years of decrepitude to the end of life. We posit that unprecedented increases in life expectancy stretch the "arc of life," making each stage of life longer and creating new ones-a phenomenon we call "the demographic stretch."

The clearest example of the demographic stretch is the transition from child to adult: the concept of "adolescence" was popularized only in the 20th century, and the term "teenager" was unknown before World War II. (G. Stanley Hall coined the term "teenager" in 1904 to describe the stage of life made possible by child labor laws and universal education, before youth faced the responsibilities of adulthood. ${ }^{4}$ ) Rather than work and marry, young people are more likely to go to college and postpone marriage, and sexual and reproductive activity may be likewise postponed or take on different guises-a phenomenon not yet fully captured by rigorous scientific studies. ${ }^{5}$ The total fertility rate (TFR) declines despite an increase in fecundity (due to earlier menarche and older age at menopause). ${ }^{6}$ Social and

\footnotetext{
a United States Agency for International Development, Washington, DC, USA.

b Johns Hopkins Bloomberg School of Public Health, Baltimore, MD, USA.

Correspondence to Sally Ann Dunst (sdunst1@jhu.edu).
}

cultural changes tend to follow the demographic changes and need to be consciously articulated.

In this paper, we explore the social and cultural implications of this "demographic stretch" and the impact of different timing across generations and geographical regions using publicly available country data from United Nations agencies and other sources. We conclude the paper with recommendations for a research agenda to better understand the demographic stretch and its drivers and implications.

\section{THE DEMOGRAPHIC TRANSITION}

For centuries, the world was relatively poor, with low life expectancy and high fertility rates. This changed with the demographic transition, which first began in France and then in the United States around the turn of the 19th century. ${ }^{2,7}$ In France, between 1750 and 2000 life expectancy more than tripled, from 25 years to 80 years. ${ }^{8}$ Similarly in the United States, life expectancy for whites nearly doubled over 150 years, increasing from 40 years in 1850 to 77 years in $2000 .^{7}$ (Prior to the 20th century, data on life expectancy of blacks in the United States, which differed significantly from that of whites due to slavery, were scarce.) Declines in fertility accompanied increases in life expectancy. In France, the fertility decline began around the 1820s, with the TFR falling from about 4 children per woman in 1800 to 2.2 children per woman in $1930 .{ }^{9}$ The TFR in the United States fell from 7.0 in 1800 to 2.3 in $1940 .^{7}$

The demographic transition occurred next in other parts of Europe, with dates of the initiation of fertility 

The demographic
transition in Africa, Asia, and Latin America is fast approaching that of richer nations. decline varying among countries. Fertility rates in Belgium, Germany, and Switzerland began to fall in the 1880s, while in Ireland and Spain fertility levels started to decline only around the 1920s. ${ }^{9}$ Life expectancy also increased. Today, more than half of babies born in rich nations will live to 100 years. ${ }^{10}$

Since 1950, regions at earlier stages in their demographic transitions have accelerated their progress with many approaching a "grand convergence $^{\prime 11}$ with richer nations: Africa, Latin America, and Asia have added 21, 24, and 29 years, respectively, to the life expectancy (Figure 1). Whereas in 1950 less than $1 \%$ of the world's population lived in countries with life expectancy of 70 years or older, now over half do. ${ }^{12}$ There has also been a dramatic convergence in TFRs. The TFRs in Latin America and Asia have reached near replacement ( 2.2 children per woman). Africa's TFR has declined since 1950 , but it is still 4.7 today. ${ }^{13}$

However, life expectancy has not increased linearly and consistently in all parts of the world, and regional averages conceal a range of country differences. In the 1990s, life expectancy stagnated in Africa and actually decreased dramatically in some countries, mainly due to the HIV/AIDS epidemic. Eastern Europe also saw a stagnation or decrease in life expectancy in the 1990s. ${ }^{12}$ Likewise, there is significant variation in the TFR within regions and within countries. Despite this variation, people generally live longer and have fewer children, decoupling sexual activity from its reproductive function.

\section{STRETCHING THE ARC OF LIFE: SOCIAL AND CULTURAL IMPLICATIONS}

Reductions in mortality across the span of life and changes in fertility patterns transform the population age structure, resulting in a net increase in median age. ${ }^{12}$ Early in the transition, progress is typically greatest in reducing under-5 mortality; reductions in older-age mortality follow. ${ }^{12}$ From

FIGURE 1. Life Expectancy at Birth and Total Fertility Rate, by World Region, 1950-2055
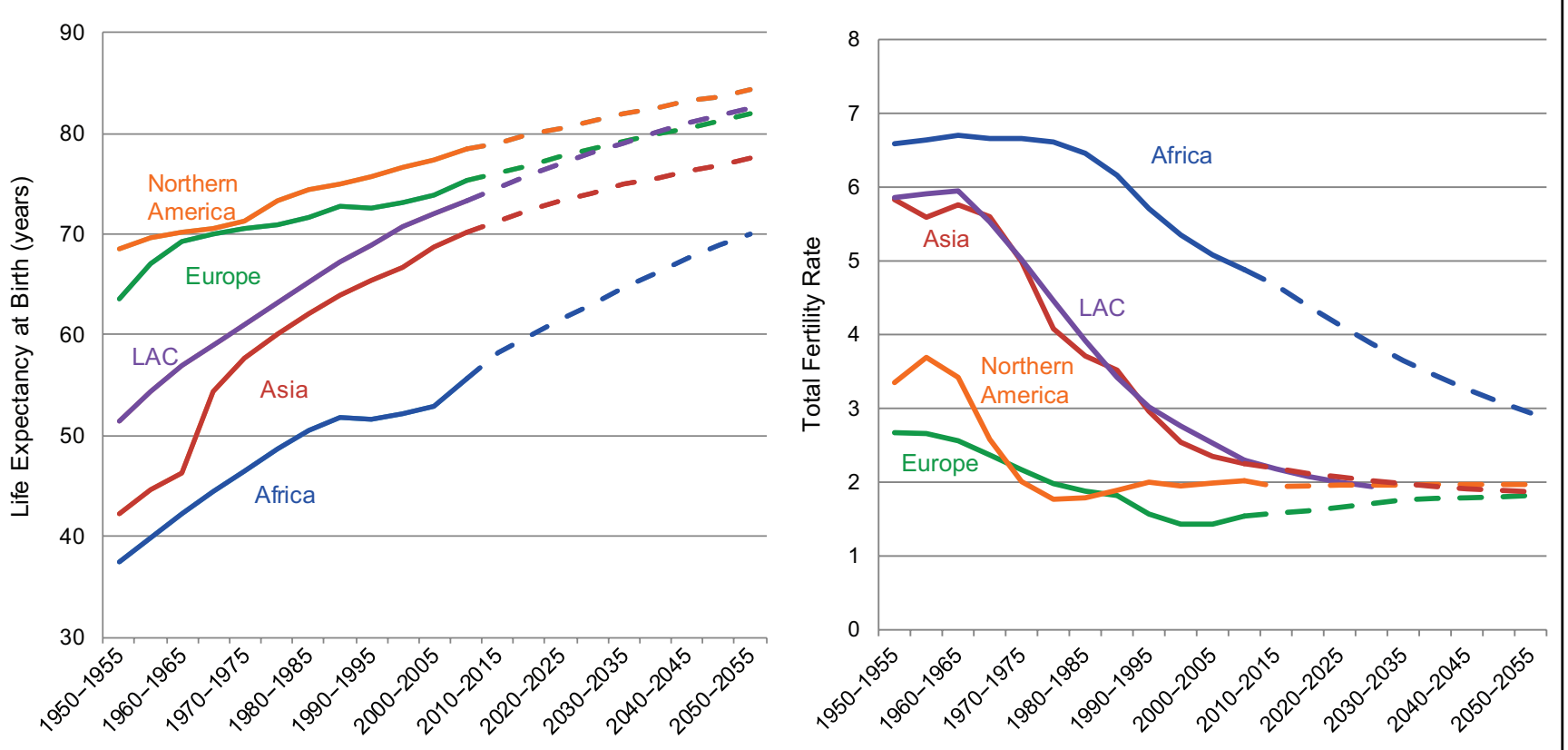

Abbreviation: LAC, Latin America and Caribbean.

Dotted lines indicate projected data.

Data Source: United Nations, 2012 (medium-variant fertility). ${ }^{13}$ 
1950 to 2010, the median age increased from 30 years to 40 years in Northern America and Europe and from 20 years to 30 years in Latin America and Asia. ${ }^{13}$ Africa's median age has stayed at about 18 or 19 years since $1950 .^{13}$ By 2050, however, Africa is expected to reach a median population age of 25 years, and Asia and Latin America will converge with Northern America and Europe at about 40 years. ${ }^{13}$

As the median age rises and fertility declines, there are initially fewer dependent children relative to those in working productive ages. This creates an opportunity for increased economic growth known as the demographic dividend. ${ }^{14}$ This demographic dividend has been well documented in countries in East Asia, such as South Korea and Thailand, ${ }^{15}$ and it is now seen as playing a significant role in the ongoing economic success in developing regions of the world. ${ }^{16}$ This opportunity may diminish as median ages advance to 50 years or beyond unless workers increase their productivity or postpone retirement. ${ }^{17}$ The epidemiologic and economic implications of longevity are well studied.

Social and cultural structures also evolve in response to the demographic stretch and the disjunction and upheaval that might accompany it. We explore such social and cultural transformations through cross-sectional, ecological associations between longevity and various dependent variables, modeled using linear and logistic regressions while adjusting for gross domestic product (GDP) per capita.

\section{Childhood Is Lengthened}

A clear, quick transition from childhood to adulthood is replaced with a more drawn-out progression through a series of sub-stages categorized by schooling (e.g., pre-Kindergarten through college) or by ages (e.g., preteen, teenager). ${ }^{18}$ In the stage of "emerging adulthood," individuals have not yet achieved independence from parents due to increases in the number of years of schooling and delays in reaching other "adult" milestones such as marriage and entry into the formal workforce. ${ }^{19}$ Young adults' continued dependence on their parents increases the cost of raising children. ${ }^{20}$ Recognizing these trends in the United States, the Affordable Care Act increased the age of health insurance eligibility in the family from 21 years to 26 years. $^{21}$

\section{Education Is Prized More}

Primary school becomes compulsory, more children complete high school, and more go on to college. In the United States, the percentage of the population completing college has grown from $5 \%$ in 1940 to $30 \%$ in $2009 .{ }^{22}$ An increase in a country's median age by 1 year is associated with an average increase of 0.24 years of schooling $(P<.001)$ (Figure 2$)$. Even after controlling for log GDP per capita, an increase in a country's median age by 1 year is associated with an average increase of 0.14 years of schooling $(P<.001)$. Societies confront issues of equity in access to education, and public subsidies of education expand into later years of schooling. In more economically advanced countries, postgraduate education becomes more common and a prerequisite for a professional career.

\section{Working Ages Are Shifted Upward}

Entry into the formal workforce and the start of a career are pushed back to older ages. This delay impacts family formation, which is often postponed to later ages as well. Increasingly, people form families and launch careers in their late 20s rather than their late teens, which was common at the start of the demographic stretch. With this transition, societies progressively protect childhood by establishing child labor laws and minimum working ages for full-time labor. These transformations occurred in North America and Europe in the late 1800s and early 1900s while efforts to end exploitative child labor practices continue in the developing world today. ${ }^{23}$

At the same time, as societies restrict child labor, the average age of retirement recedes to older ages. This can create disjunctions if retirement systems and health insurance benefits do not keep pace with longer life expectancies. For example, violent protests in Greece and elsewhere have broken out in recent years in response to proposals to increase the retirement age and cut pensions. ${ }^{24}$ In the United States, debate is ongoing regarding changing the national social security system that provides benefits to retired workers. Because of the increase in life expectancy, the system may need to raise the onset of retirement payments to later years in order to ensure its solvency. ${ }^{25}$

The upward shift in the working age calls for a redefinition of how we view "dependency." Demographers classify children under age 15 as dependent, with the implication that once reaching age 15, children become independent. While this may have typified agrarian societies, it does not reflect the realities of today. Research using national transfer accounts data shows that for
The demographic transition results in a net increase in median age of populations.

\section{Entry into the workforce, along with family formation, is pushed back to later ages as a result of the demographic transition.}


most all countries, individual levels of consumption outweigh production at ages well into the $20 \mathrm{~s}$, and in some cases into the early 30s. ${ }^{17}$ The threshold for old-age dependency, at times 60 years or 65 years, likewise, needs to be rethought as retirement is pushed to higher ages and as older people remain active and independent.

\section{Marriage Is Delayed While Non-Marital Childbearing and Cohabitation Increase}

Longer childhood, more schooling, decreased fertility expectations, and later entry into the workforce delay marriage for both men and women. In 1880s Russia, an unmarried woman of 24 years was considered a "spinster." ${ }^{26}$ Today, a woman unmarried in her 20s would be commonplace in many parts of the world. In the United States, between 1950 and 2009, the median age at first marriage increased from 23 years to 28 years for men and from 20 years to 26 years for women. ${ }^{27}$ A similar trend has already been noted in many developing countries such as India, ${ }^{28}$ Côte d'Ivoire, ${ }^{29}$ and Senegal. $^{29}$ As shown in Figure 3, there is a significant association between median population age and age at first marriage, which is deferred, on average, by 0.35 years for females $(P<.001)$ and by 0.26 years for males $(P<.001)$ as median population age rises by 1 year. When controlling for log GDP per capita, median age at first marriage is delayed by 0.16 years for females $(P<.001)$ and 0.14 years for males $(P<.001)$, on average, with each year increase in a country's median age.

Cohabitation shifts from a taboo to a commonplace precursor or alternative to marriage. In the United States, the rate of cohabitation has increased from near zero 100 years ago to $33 \%$ in 1987 and to $50 \%$ in $2002 .^{30}$ Global comparisons show that non-marital cohabitation is common in more developed regions, including the Americas, Europe, and Oceania, while it is still rare in other regions. ${ }^{30}$ With delays in marriage sometimes come increases in out-of-wedlock births. In Iceland, $66 \%$ of births are to unmarried women,

FIGURE 2. Relationship Between Average Years of Schooling and Median Population Age (138 Countries)

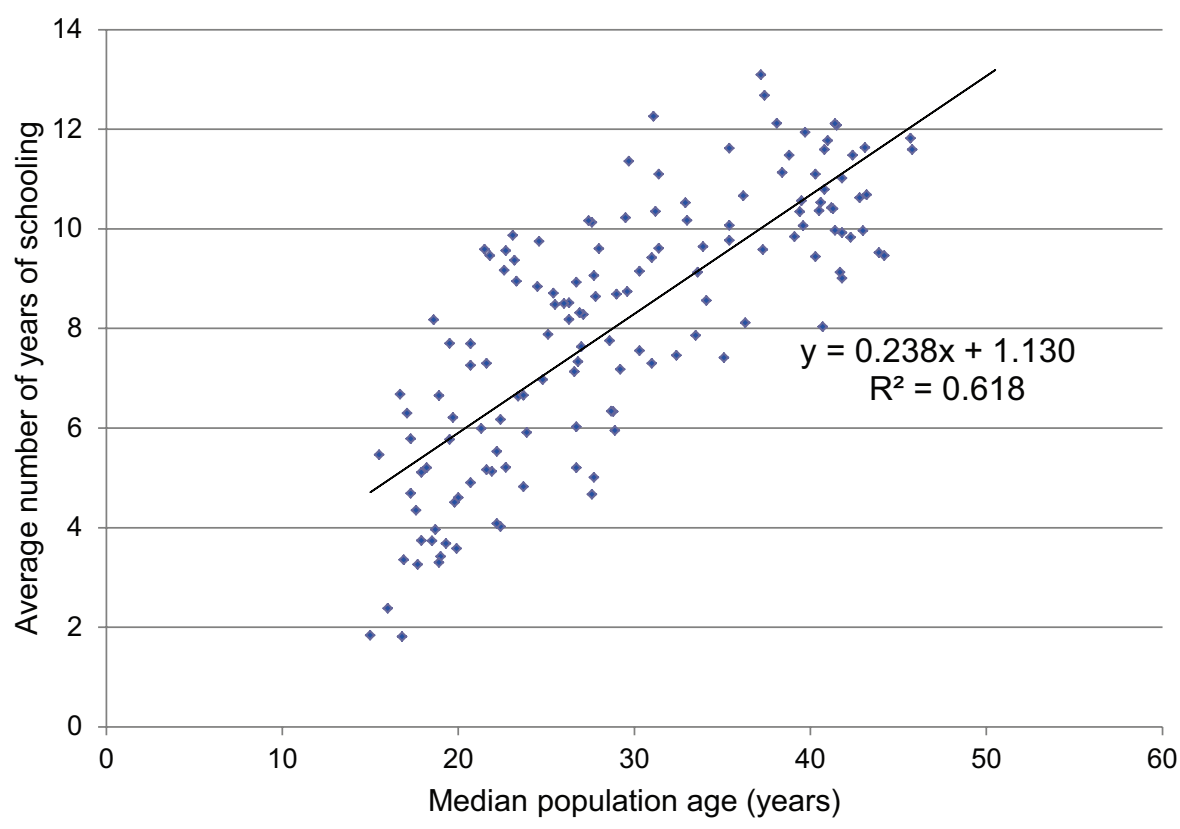

Data Sources: Median population age in 2013 from The Kaiser Family Foundation Global Health Facts, ${ }^{52}$ and average years of total schooling lage $15+$ in 2005-2011) are from the World Bank Open Data. ${ }^{53}$ 
and in Sweden this proportion is $55 \% .^{31}$ In the United States, about $40 \%$ of children are born to unmarried mothers; this proportion was just 5\% in $1960 .{ }^{31,32}$ Having children within a cohabiting union becomes more common as cohabiting couples who become pregnant feel less pressure to wed. About $60 \%$ of out-of-wedlock births in the United States are to cohabiting couples. ${ }^{32}$

\section{Childbearing Is Delayed and Teenage Pregnancy Declines}

The average age of a US mother at first birth increased from 21.4 years in 1970 to 25.0 years in 2006. ${ }^{33}$ Similar trends have occurred in other countries of the Organisation for Economic Cooperation and Development (OECD), where there has been a near-universal shift in age at first birth from the late teens to the late twenties. ${ }^{33}$ With greater access to contraceptives for youth, the rate of teen childbearing has declined significantly in Europe and North America (including among black and Hispanic teenagers); all the while, the proportion of teen births to unmarried youth has increased significantly-from less than $15 \%$ to $80 \%$ in the United States over the last 50 years (Figure 4). ${ }^{34}$ Sexual education and family planning have been critical to the decline in overall teenage pregnancy in the context of delayed marriage.

In the United States in 1970, only 1 of 100 first births were to women 35 years and older; in 2006 this proportion was 1 of $12 .{ }^{33}$ Postponement of childbearing increases the mean length between generations and results in a changing "tempo" of childbearing. ${ }^{35}$ As postponements push childbearing into ages with lower fecundity, interest increases in induced ovulation methods, which produce greater chances for twins/multiple births. Rates of multiple
Age at first birth in the United States and other developed countries has increased to the late 20s.

FIGURE 3. Relationship Between Median Age of the Population and Average Age at First Marriage (120 Countries)

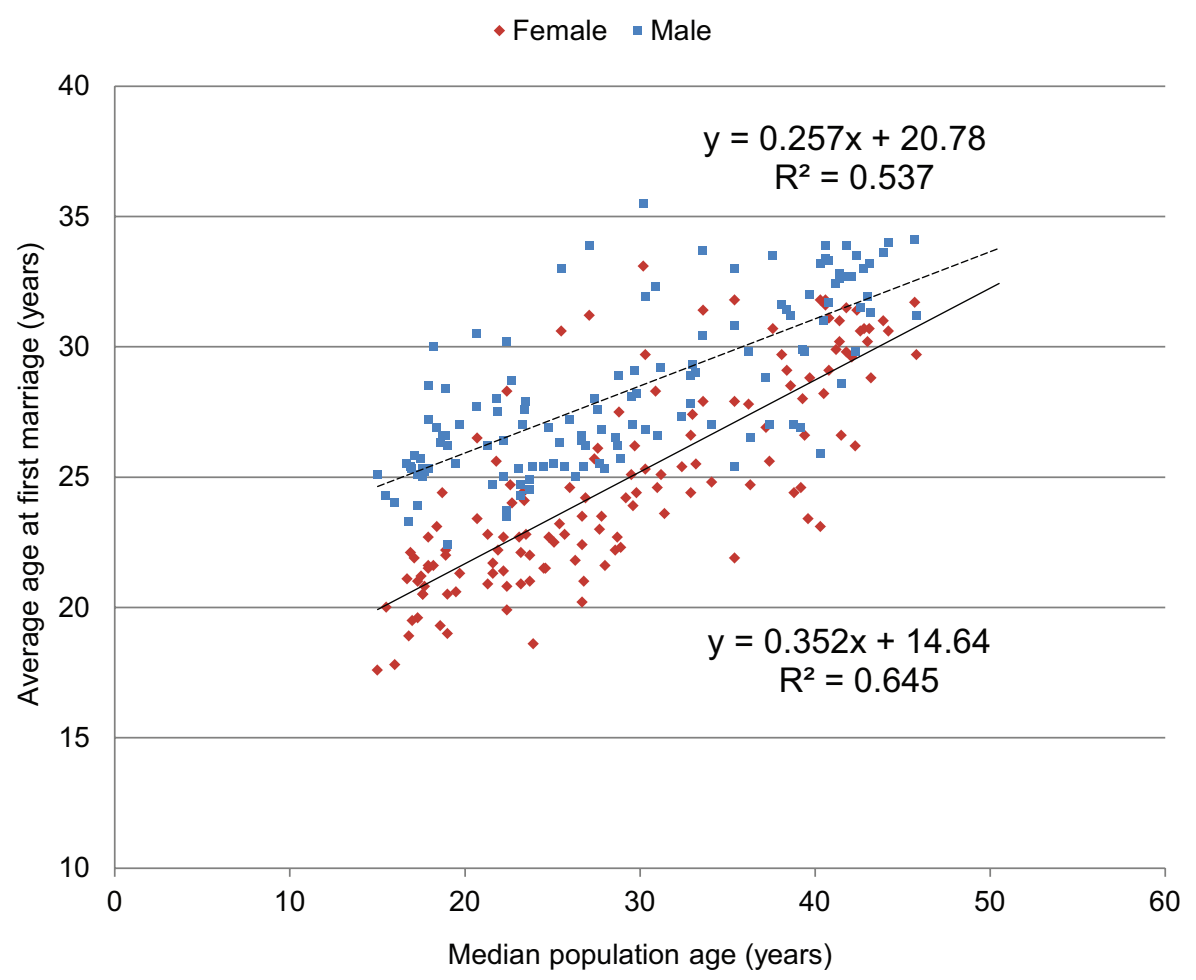

Data Sources: Median population age in 2013 from The Kaiser Family Foundation Global Health Facts, ${ }^{52}$ and average age at first marriage (in 2005-201 1) are from the World Bank Open Data. ${ }^{53}$ 
births have increased substantially in many developed countries, including Canada, England and Wales, France, and the United States, over the past few decades in part because of increased maternal age and fertility treatment. ${ }^{36}$ These multiple births are associated with increased risk factors for infant mortality and long-term morbidity such as preterm birth and low birth weight. Increased maternal age is also associated with increased risk of congenital defects and gestational diabetes. ${ }^{37}$ However, the decrease in the number of children in families leads to higher investments in children. Parents with fewer children are able to spend more time with children and provide them with more resources and support. $^{38}$

\section{Women's Status and Equity Evolves}

A central feature of these transitions is the changing role of women in society. With reductions in fertility, women experience greater opportunity for social participation. Gender gaps in education, work opportunities, income levels, and legal rights generally narrow. Control of fertility allows women to engage in educational, economic, and political activities and leads to changes in traditional gender roles. ${ }^{16,38,39}$ In the United States, women have outnumbered men in higher education since the late 1970s. ${ }^{40}$ Even Muslim-majority countries, which are often criticized for constraining women's rights, have experienced concomitant increases in contraceptive use and equitable access to education over the past few decades. ${ }^{41}$ In Iran, where about $60 \%$ of women use a modern method of family planning and the TFR is 1.9, nearly equal proportions of males and females are enrolled in primary, secondary, and tertiary levels of school. ${ }^{42,43}$ In Egypt and Indonesia, the contraceptive prevalence rate and the male-to-female school enrollment ratio are about the same as in Iran, although fertility rates are slightly higher. ${ }^{42,43}$ Despite

FIGURE 4. Births to Teenagers in the United States, $1950-2000$

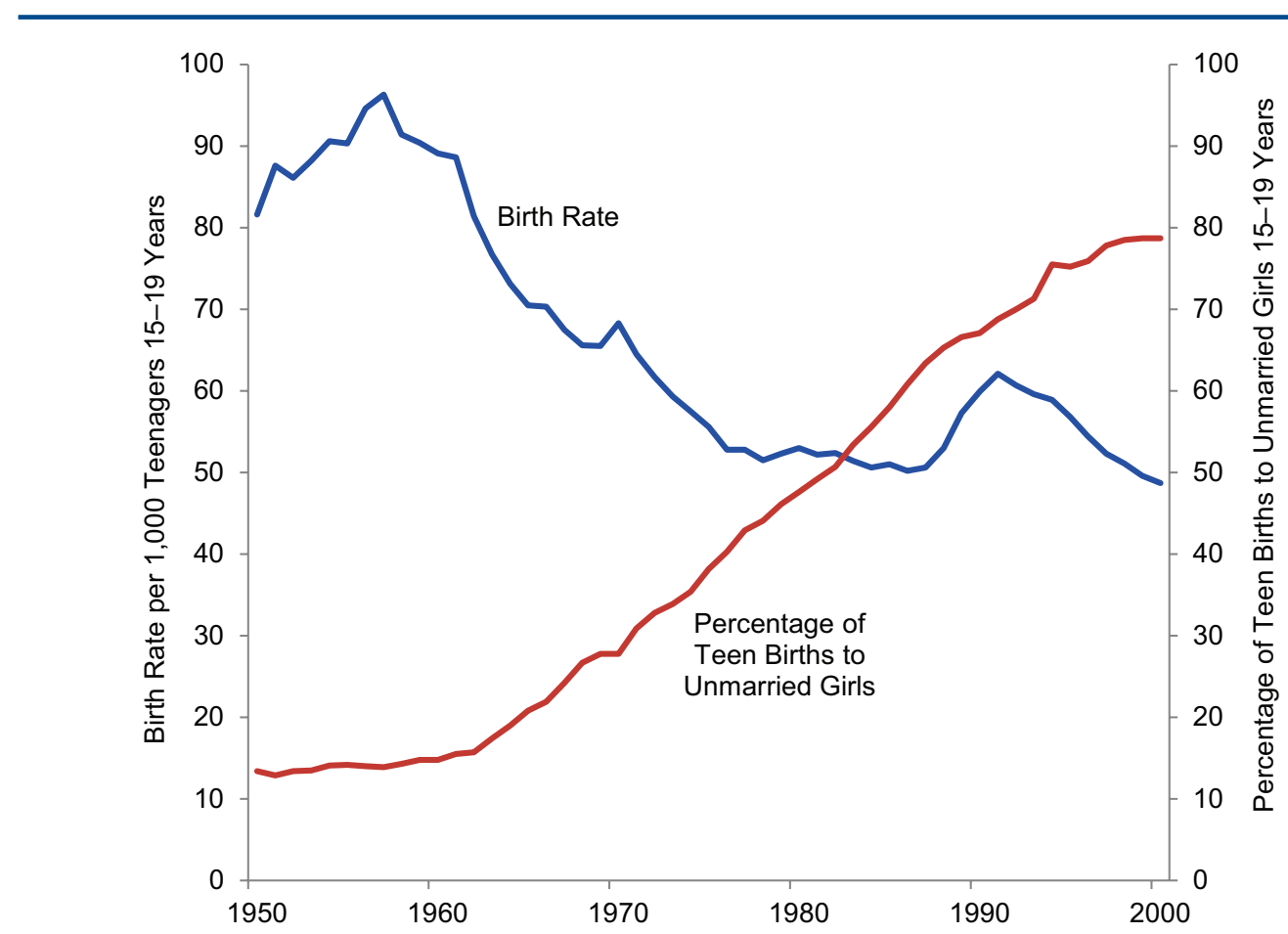

Source: Reproduced from the National Center for Health Statistics, 2001.54 
progress in gender equality in educational attainment, women in these countries lag behind men in workforce and political participation, highlighting that progress in all aspects of women's empowerment is not automatic and immediate. In fact, we did not find a simple correlation between nations' life expectancy (or their GDP) and the proportion of women working.

\section{Non-Traditional Lifestyles Are Increasingly Accepted}

Not only are there overall delays in the initiation of life stages with the demographic stretch, there is also increasing freedom to deviate altogether from the traditional sequence of marriage followed by childbearing. Individuals and couples have increasingly chosen to remain childless. In some developed countries such as Australia,
Germany, Italy, and the United States, the proportion of women in their late 40s who have no children has doubled over the past 30 years. ${ }^{44}$ As shown in Figure 5, countries with higher median population ages have higher rates of women ages $45-49$ with no children $(P<.001)$, although this relationship is not statistically significant after adjusting for log GDP per capita.

As sexual activity is decoupled from reproduction, people are more able to explore, discover, or assert different sexual orientations. Societies increasingly accept homosexuality and, more recently, have come to accept same-sex unions. Based on recent reports, 76 (41\%) of 184 countries criminalize homosexuality. ${ }^{45}$ Figure 6 demonstrates that countries with the lowest life expectancies are least tolerant of homosexuality $(72 \%$ of such countries criminalize homosexuality), and those with the highest life expectancies criminalize it the

FIGURE 5. Relationship Between Median Age of the Population and the Percentage of Women Ages 45-49 Remaining Childless (92 Countries)

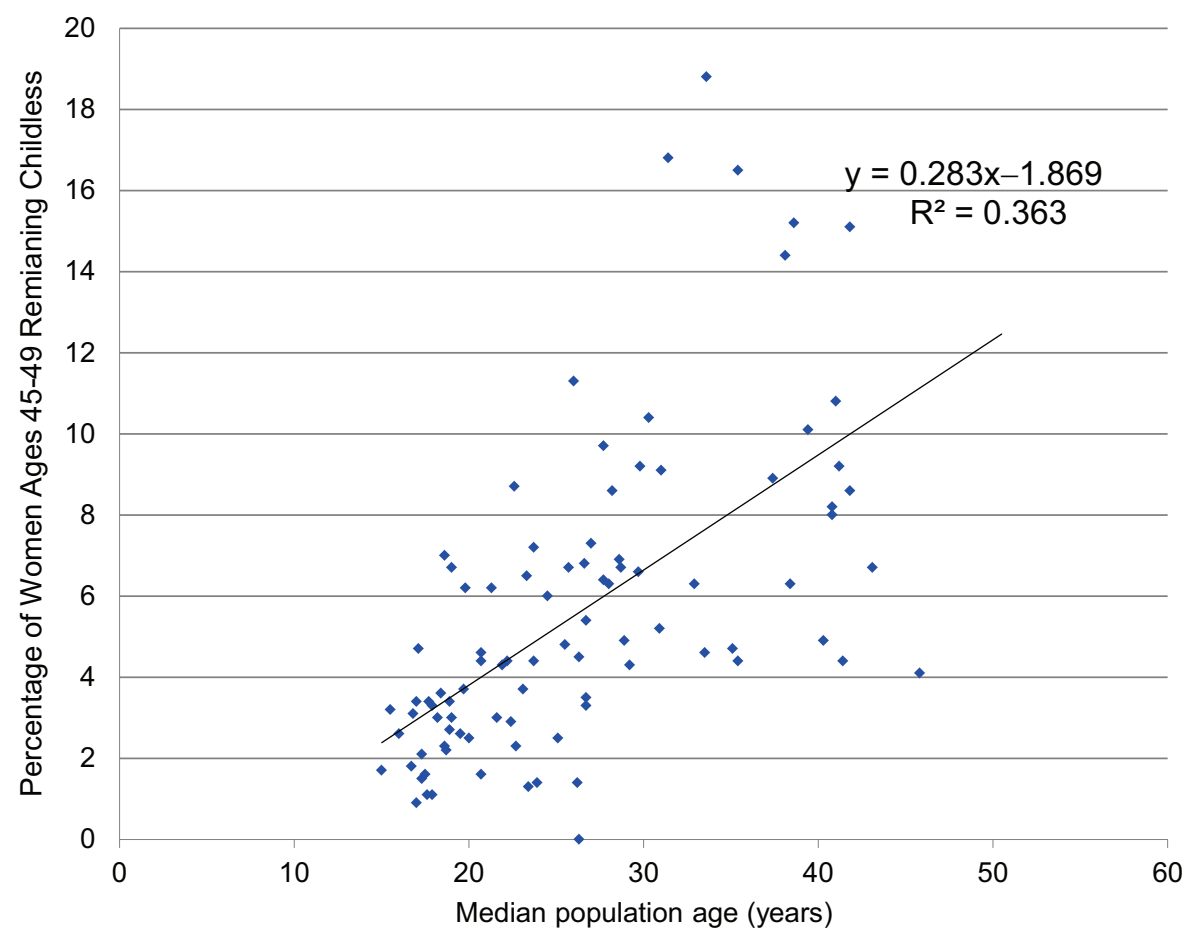

Data Sources: Median population age in 2013 from The Kaiser Family Foundation Global Health Facts, 52 and the percentage of childless women (in the most recent year available between 2000 and 2008) are from the United Nations, 2009.55 
The burden of chronic disease and disability is pushed to older ages with the demographic transition. least ( $12 \%$ of such countries). In a logistic regression model, controlling for log GDP per capita, each 1 -year increase in life expectancy is associated with a $12 \%$ decrease, on average, in the odds that a country criminalizes homosexuality $(P=.006)$. The causal relationship here needs further exploration (e.g., what role do education, increasing secularization, or the decoupling of sexuality and reproduction have?). Clearly, tradition and political will can still strongly affect policy: 3 of the 4 high life expectancy countries that criminalize homosexuality have majority Muslim populations (Brunei, Lebanon, and Qatar). On the other hand, South Africa with a relatively low life expectancy has laws protective of sexual choice.

\section{Good Health Continues Through Middle Age and Often Beyond}

The epidemiologic transition that follows the demographic one brings chronic diseases to the fore. $^{46}$ The burden of chronic disease and disability increases ${ }^{47}$ but is pushed to older ages, ${ }^{48}$ and the functional status of individual octogenarians improves over previous generations. As new cohorts imprinted by the demographic stretch reach old age, sexual behaviors evolve since attitudes are more significant influences on sexual desire than biomedical factors. ${ }^{49}$ Many people remain sexually active after retirement: in the United States, $67 \%$ of 65 - to 74 -year-old men and $40 \%$ of women are sexually active. ${ }^{50}$ For 75 - to 85 -year-olds, $39 \%$ of men and $17 \%$ of women are sexually active. ${ }^{50}$

\section{DISCUSSION}

The world has undergone an unprecedented transition from high levels of fertility and mortality to much lower levels. The transition has not been uniform in onset or pace across countries, but it is nearly universal and progressing. It began 2 centuries ago in the countries of Europe and North America that are now considered "more

FIGURE 6. Relationship Between Life Expectancy and Criminalization of Homosexuality (182 Countries)

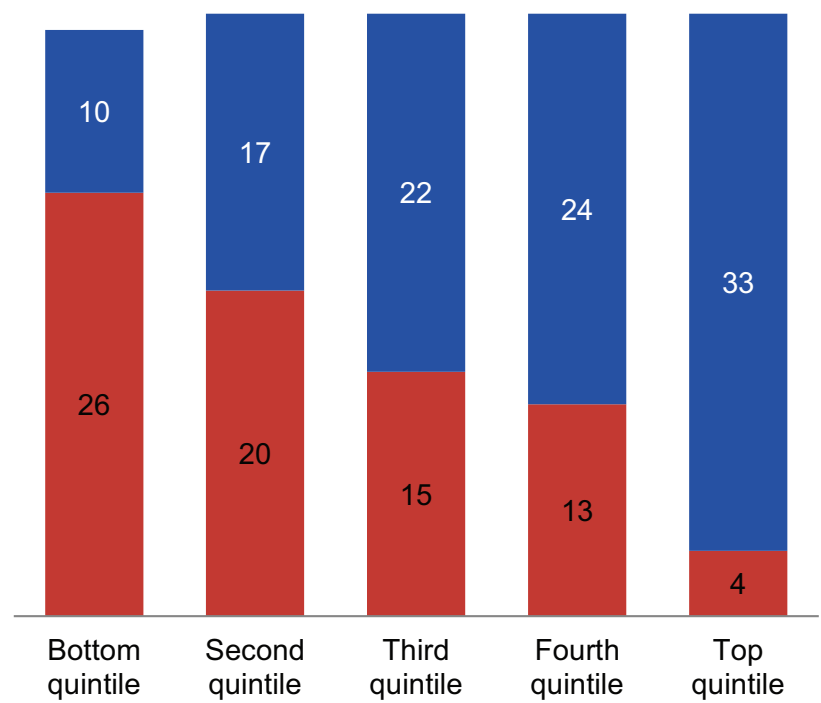

Life Expectancy
No. of countries where homosexuality is not criminalized

No. of countries where homosexuality is criminalized

Data Sources: Data on criminalization of homosexuality are from Clark, 2014, ${ }^{45}$ and data on life expectancy are from the United Nations, $2012 .^{13}$ 
developed" and has been followed in the past 50 years in many countries in Asia, Africa, and Latin America-and often at a much faster pace than in the more developed world. The transition continues today as child survival and fertility rates in poor countries converge with those of upper middle-income countries. This paper posits that these demographic shifts lead to a demographic stretch of the arc of life. Added years of life do not simply translate to added years of decrepitude. Rather, each stage of life is extended: we spend more years in childhood, more years as healthy adults, and more years in retirement. New substages of life are added (e.g., "teenage"), and complex social changes emerge with some degree of predictability based on demographic transitions.

These shifts in the arc of life are not smooth or without economic and social upheavals: the staggered transition across generations, socioeconomic groups, and whole nations may create tensions due to the asynchronous evolution of norms in different groups or populations. At the macroeconomic level, they can require changes in the social contract, for example, in the need to raise the age at which retirement and health benefits become available. At the social level and in private life, we see impacts of the demographic stretch on child transitions to adulthood, transitions in family formation, and the role of women in society. The age of marriage moves from the teens to the late twenties, and sexual activity is decoupled from biological reproduction. The asynchronous nature of change means that moral and legal norms and the power relationships and attitudes they reflect may collide with the rapid demographic changes visiting the modern world, for example, in the recognition of gender equality or the acceptance of same-sex relationships.

The preliminary associations presented here are just that: simple, descriptive, ecological observations that suggest the need for a research agenda to better understand the drivers of the demographic stretch of the arc of life changes, and of their implications. No single variable can explain complex sociocultural phenomena. The demographic stretch is the result of a complex interplay of increasing life expectancy, greater economic wealth, lower fertility rates, and the empowerment of women; changes in life expectancy and fertility correlate with such important variables as income and education, and sexuality measurement is far from perfect in much of the world. Rapid changes in information and communication technology and continued globalization will no doubt accelerate the changes. Panel data and time series analyses are needed to better understand the complex causal paths and interactions suggested by our hypothesis of a demographic stretch-in the context of a rich literature from psychology and anthropology. This growing understanding will help us develop a useful framework that will help policy makers and opinion leaders anticipate change and prepare for it.

The evidence presented here suggests the demographic stretch is a natural phenomenon followed rather predictably by changes in behaviors and social norms. It cannot by itself explain changing gender roles, sexual orientation, or the social acceptance of either phenomenon, but it does provide insight into the direction and drivers of change and is therefore a useful indicator of change. Countries that have undergone the demographic stretch cannot ignore their own historical evolution nor expect others to simply skip it as we do in more technical areas such as decreasing child mortality. In responding to countries where human rights appear to have been limited by local law or customs, being aware of the demographic stretch might help fast-track reform through more creative and effective approaches.

The demographic transition is well underway through much of the world. What might we expect to see as the arc of life continues to stretch? In countries where the transition is more advanced, we would expect to see more intergenerational conflict over, and changes in laws relating to, social welfare programs that benefit the elderly as declining numbers of younger people support increasing numbers of older people. We might see more countries entering a "birth dearth," i.e., birth rates falling significantly below replacement levels, which Japan and other places are experiencing. While there will be economic consequences, these countries will still continue to see an increase in life expectancies and the demographic stretch. We look for further shifts toward later working ages as demand for labor increases relative to supply (and as life expectancies continue to increase), and possibly for the relaxing of and/or adjustments to immigration policies to address labor shortages.

At the other end of the wealth spectrum, lowincome countries are witnessing the start of the transition. As their economies begin to expand,

\section{Added years of life do not simply translate to added years of decrepitude.}

The shifts in the arc of life may pose economic and social challenges that countries must address.

\section{In countries where the demographic transition is advanced, more intergenerational conflict may be expected.}


With faster spread and with the faster spread of ideas through of ideas through technology, we anticipate accelerated transitions technology, accelerated transitions might be expected in low-income countries at the start of the demographic transition. over the next few decades-perhaps in a more compressed time period than observed elsewhere. Total fertility rates in the 48 least developed countries have been historically high but are beginning to fall, today at 4.3 compared with 5.7 children per woman just 40 years ago. ${ }^{51}$ Life expectancies have been historically low but are now rapidly increasing, today at 61 years compared with 44 years just 40 years ago. ${ }^{51}$ These countries have an aggregate population of 916 million, $40 \%$ of whom are less than 15 years old. ${ }^{51}$ For these countries, the social and economic changes that we have witnessed elsewhere and described in this paper could be amplified. We look for these countries to move at an accelerated pace toward social and political liberalization although with potential for a conservative backlash as social institutions and more traditional segments of a population resist these rapid changes.

\section{Competing Interests: None declared.}

\section{REFERENCES}

1. Caldwell JC, Caldwell BK, Caldwell P, McDonald PF, Schindlmayr T. Demographic transition theory. Dordrecht (Netherlands): Springer; 2006.

2. Coale AJ. The demographic transition reconsidered. In: Proceedings of the International Population Conference, Liege, 1973. Liege International Union for the Scientific Study of Population. p. 53-72.

3. Wrigley EA. Population and history. London: McGraw-Hill; 1969.

4. Massachusetts Cultural Council (MCC) [Internet]. Boston: MCC; c1999-2015. Boston Youth Arts Evaluation Project: brief history of adolescence and youth development; c2015 [cited 2015 Jun 30]. Available from: http://www.massculturalcouncil.org/ services/BYAEP_History.asp

5. Morris A. Tales from the millennials' sexual revolution. Rolling Stone Magazine. 2014 Mar 21. Available from: http://www. rollingstone.com/feature/millennial-sexual-revolutionrelationships-marriage

6. Nichols HB, Trentham-Dietz A, Hampton JM, Titus-Ernstoff L, Egan KM, Willett WC, et al. From menarche to menopause: trends among US women born from 1912 to 1969. Am J Epidemiol. 2006;164(10): 1003-1011. CrossRef. Medline

7. Haines M. Fertility and mortality in the United States. In: Whaples R, editor. EH.net Encyclopedia. 2010. Available from: https://eh. net/encyclopedia/fertility-and-mortality-in-the-united-states/

8. Pison G. France 2004: life expectancy tops 80 years. Pop Societies. 2005;(10). Available from: https://www.ined.fr/en/ publications/population-and-societies/france-2004-lifeexpectancy-tops-80-years-en/

9. Coale AJ, Watkins SC, editors. The decline of fertility in Europe: the revised proceedings of a conference on the Princeton European Fertility Project. Princeton (NJ): Princeton University Press; 1986.
10. Christensen K, Doblhammer G, Rau R, Vaupel JW. Ageing populations: the challenges ahead. Lancet. 2009;374(9696): 1196-1208. CrossRef. Medline

11. Jamison DT, Summers LH, Alleyne G, Arrow KJ, Berkley S, Binagwaho A, et al. Global health 2035: a world converging within a generation. Lancet. 2013;382(9908): 1898-1955. CrossRef. Medline

12. United Nations (UN), Department of Economic and Social Affairs, Population Division. World population prospects: the 2004 revision, volume III: analytical report. New York: UN; 2005. Available from: http://www.un.org/esa/population/ publications/WPP2004/wpp2004.htm

13. United Nations (UN), Department of Economic and Social Affairs, Population Division. World population prospects: the 2012 revision. New York: UN; 2013. Available from: http://esa. un.org/unpd/wpp/index.htm

14. Bloom DE, Canning D. Demographics and development policy. Dev Outreach. 2011;13(1): 77-81. CrossRef.

15. Gribble JN, Bremner J. Achieving a demographic dividend. Pop Bull. 2012;67(2). Available from: http://www.prb.org/pdf12/ achieving-demographic-dividend.pdf

16. Bongaarts J, Sinding SW. Family planning as an economic investment. SAIS Rev Int Affairs. 2011;31(2): 35-44. CrossRef

17. Lee $R$, Mason A. Population aging and the generational economy: a global perspective. Cheltenham (UK): Edward Elgar; 2011. Available from: http://www.idrc.ca/EN/Resources/ Publications/Pages/IDRCBookDetails.aspx?PublicationID=987

18. Baltes $P B$, Lindenberger $U$, Staudinger UM. Life-span theory in developmental psychology. In: Damon W, Lerner RM, editors. Handbook of child psychology volume 1: theoretical models of human development. New York: Wiley; 1998. p. 1029-1143. Available from: http://library.mpib-berlin.mpg.de/ft/pb/ pb_life_2006.pdf

19. Arnett JJ. Emerging adulthood: a theory of development from the late teens through the twenties. Am Psychol. 2000;55(5): 469480. CrossRef. Medline.

20. Furstenberg FF Jr. On a new schedule: transitions to adulthood and family change. Future Child. 2010;20(1): 67-87. Medline

21. Office of the Legislative Counsel for the use of the U.S. House of Representatives. Compilation of Patient Protection and Affordable Care Act. Washington (DC): Office of the Legislative Counsel; 2010. Available from: http://docs.house.gov/energycommerce/ ppacacon.pdf

22. Ryan CL, Siebens J. Educational attainment in the United States: 2009. Washington (DC): United States Census Bureau; 2012. Available from: http://mww.census.gov/prod/2012pubs/p20-566.pdf

23. Cunningham $H$,Viazzo PP, editors. Child labour in historical perspective: 1800-1985. Florence (ltaly): United Nations Children's Fund; 1996. Available from: http://www.unicef-irc. org/publications/pdf/hisper_childlabour_low.pdf

24. Greece agrees to raise retirement age, discusses further cuts. RT. 2012 Sep 21. Available from: http://rt.com/business/greeceretirement-troika-cuts-620/

25. The Congress of the United States, Congressional Budget Office. Social security policy options. Washington (DC): Congressional Budget Office; 2010. Available from: http://www.cbo.gov/ publication/21547

26. Dostoyevsky F. The Brothers Karamazov. In: The Russian Messenger. 1880.

27. Kreider RM, Ellis R. Number, timing, and duration of marriages and divorces: 2009. Washington (DC): United States Census Bureau; 2011. Available from: http://www.census.gov/prod/ 2011 pubs/p70-125.pdf 
28. United Nations (UN), Department of Economic and Social Affairs, Population Division. World marriage data 2012: singulate mean age at marriage. New York: UN; 2013. Available from: http://www.un.org/esa/population/ publications/WMD2012/MainFrame.html

29. Garenne M. Age at marriage and modernisation in sub-Saharan Africa. SAJ Dem. 2004;9(2): 59-79. Available from: https:// www.commerce.uct.ac.za/Organisations/Demography/ SA_Journal_of_Demography/SAJD/Volume\%209\%202/ SAJDem_2004_9_2_Garenne.pdf

30. Child Trends. Mapping family change and child well-being outcomes. Bethesda (MD): Child Trends; 2013. Available from: http://worldfamilymap.org/2013/wp-content/uploads/2013/ 01/WFM-2013-Final-lores-11513.pdf

31. Harris G. Out-of-wedlock birthrates are soaring, U.S. reports. New York Times. 2009 May 13. Available from: http://www. nytimes.com/2009/05/13/health/13mothers.html?_r $=0$

32. Martin JA, Hamilton BE, Ventura SJ, Osterman MJ, Mathews TJ. Births: final data for 2011. Natl Vital Stat Rep. 2013;62(1): 169, 72. Medline. Free full-text available from: http://www.cdc. gov/nchs/data/nvsr/nvsr62/nvsr62_01.pdf

33. Mathews TJ, Hamilton BE. Delayed childbearing: more women are having their first child later in life. Hyattsville (MD): National Center for Health Statistics; 2009. Available from: http://www. cdc.gov/nchs/data/databriefs/db21.pdf

34. Boonstra $H$. Teen pregnancy: trends and lessons learned. Issues Brief (Alan Guttmacher Inst). 2002;(1): 1-4. Medline. Free fulltext available from: https://www.guttmacher.org/pubs/tgr/05/ 1/gr050107.html

35. Bongaarts J, Feeney $G$. On the quantum and tempo of fertility. Popul Dev Rev. 1998;24(2): 271-291. CrossRef

36. Blondel B, Kaminski M. Trends in the occurrence, determinants, and consequences of multiple births. Semin Perinatol. 2002;26 (4): 239-249. CrossRef. Medline

37. Balasch J, Gratacós E. Delayed childbearing: effects on fertility and the outcome of pregnancy. Curr Opin Obstet Gynecol. 2012;24(3): 187-193. CrossRef Medline

38. Sonfield A, Hasstedt K, Kavanaugh ML, Anderson R. The social and economic benefits of women's ability to determine whether and when to have children. New York: Guttmacher Institute; 2013. Available from: http://www. guttmacher.org/pubs/socialeconomic-benefits.pdf

39. Canning D, Schultz TP. The economic consequences of reproductive health and family planning. Lancet. 2012;380 (9837): 165-171. CrossRef. Medline

40. Borzelleca D. The male-female ratio in college. Forbes. 2012 Feb 16. Available from: http://www.forbes.com/sites/ccap/ 2012/02/16/the-male-female-ratio-in-college/

41. Abbasi-Shavazi MJ, Torabi F. Women's education and fertility in Islamic countries. In: Groth H,Sousa-Poza A, editors. Population dynamics in Muslim countries: assembling the jigsaw. Berlin: Springer-Verlag; 2012.

42. Hausmann $R$, Tyson LD, Zahidi $S$. The global gender gap report 2012. Geneva: World Economic Forum; 2012. Available from: http://www3.weforum.org/docs/WEF_GenderGap_Report_ 2012.pdf

43. Clifton D, Kaneda T. Family planning worldwide 2013 data sheet. Washington (DC): Population Reference Bureau; 2013. Available from: http://www.prb.org/Publications/Datasheets/ 2013/family-planning-worldwide-2013.aspx

44. Chamie J, Mirkin B. Childless by choice. YaleGlobal Online. 2012 [cited 2015 Jul 15]. Available from: http://yaleglobal. yale.edu/content/childless-choice

45. Clark F. Discrimination against LGBT people triggers health concerns. Lancet. 2014;383(9916): 500-502. CrossRef. Medline

46. Omran AR. The epidemiologic transition: a theory of the epidemiology of population change. Milbank Mem Fund Q. 1971;49: 6-47. Medline

47. Lim SS, Vos T, Flaxman AD, Danaei G, Shibuya K, Adair-Rohani $\mathrm{H}$, et al. A comparative risk assessment of burden of disease and injury attributable to 67 risk factors and risk factor clusters in 21 regions, 1990-2010: a systematic analysis for the Global Burden of Disease Study 2010. Lancet. 2012;380(9859): 2224-2260. CrossRef. Medline

48. Fries JF. The compression of morbidity. Milbank Q. 2005;83(4): 801-823. CrossRef. Medline

49. DeLamater JD, Sill M. Sexual desire in later life. J Sex Res. 2005;42(2): 138-149. CrossRef. Medline

50. Tessler Lindau S, Gavrilova N. Sex, health, and years of sexually active life gained due to good health: evidence from two US population based cross sectional surveys of ageing. BMJ. 2010;340:c810. CrossRef. Medline

51. Population Reference Bureau (PRB). 2014 world population data sheet. Washington (DC): PRB; 2014. Available from: http:// www.prb.org/pdf1 4/2014-world-population-data-sheet_eng. pdf

52. The Kaiser Family Foundation, Global Health Facts [Internet]. Washington (DC): Kaiser Family Foundation. Median age (years); [cited $2015 \mathrm{Jul} 6$ ]. Available from: http://kff.org/globalindicator/median-age/

53. World DataBank [Internet]. Washington (DC): World Bank; [cited 2015 Jul 6]. Available from: http://databank.worldbank. org/data

54. Ventura SJ, Matthews TJ, Hamilton BE. Birth to teenagers in the United States, 1940-2000. Natl Vital Stat Rep. 2001;49(10): 1-23. Medline

55. United Nations (UN), Department of Economic and Social Affairs, Population Division. World fertility report 2009. New York: UN; 2011. Available from: http://www.un.org/esa/ population/publications/WFR2009_Web/Main.html

\section{Peer Reviewed}

Received: 2014 Oct 13; Accepted: 2015 Apr 21

Cite this article as: Pablos-Mendez A, Radloff SR, Khajavi K, Dunst SA. The demographic stretch of the arc of life: social and cultural changes that follow the demographic transition. Glob Health Sci Pract. 2015;3(3):341-351. http://dx.doi.org/10.9745/GHSP-D-14-00175.

(c) Pablos-Mendez et al. This is an open-access article distributed under the terms of the Creative Commons Attribution License, which permits unrestricted use, distribution, and reproduction in any medium, provided the original author and source are properly cited. To view a copy of the license, visit http://creativecommons.org/licenses/by/3.0/. When linking to this article, please use the following permanent link: http://dx.doi.org/10.9745/GHSP-D-14-00175. 